\title{
A Short Synthesis of 10-Hydroxy 7-Spiro-Cyclopropyl Camphor
}

\author{
Yu-Rong Yang ${ }^{\dagger}$ and Wei-Dong Z. $\mathrm{Li}^{* \dagger+\dagger}$ \\ State Key Laboratory of Applied Organic Chemistry, Lanzhou University, Lanzhou 730000, China \\ $*$ \\ State Key Laboratory of Elemento-organic Chemistry, Nankai University, Tianjin 300071, China \\ liwd@1zu.edu.cn; wdli@nankai.edu.cn
}

\section{Table of Contents}

1. Experimental procedures and spectral data of compounds $\mathbf{4 a}$ and $\mathbf{4 b}$ b..........S2

2. Experimental procedures and spectral data of compounds $4 \mathrm{c}$ and $12 \ldots \ldots \ldots . . . . .53$

3. Experimental procedures and spectral data of compounds 13a and 13............S4

4. Experimental procedures and spectral data of compounds 16 and I..............S5

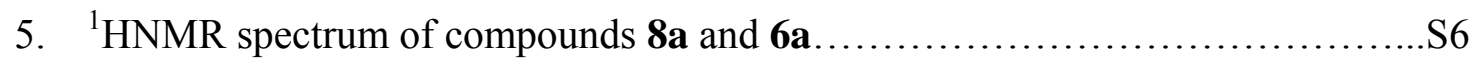

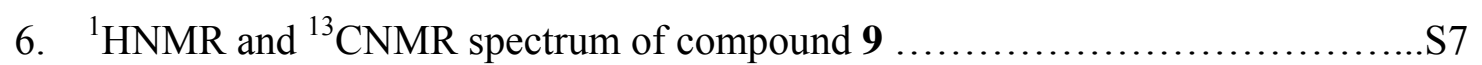

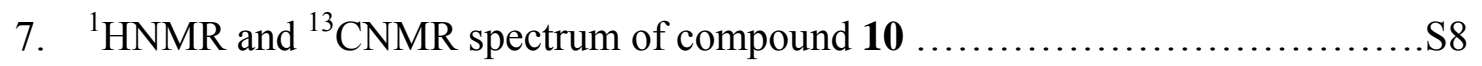

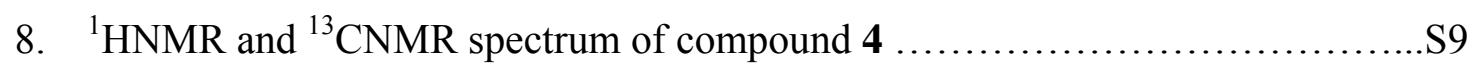

9. ${ }^{1} \mathrm{HNMR}$ and ${ }^{13} \mathrm{CNMR}$ spectrum of compound 2a ............................ 10

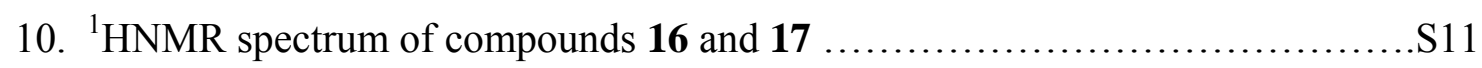

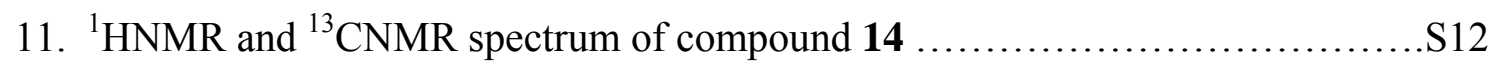

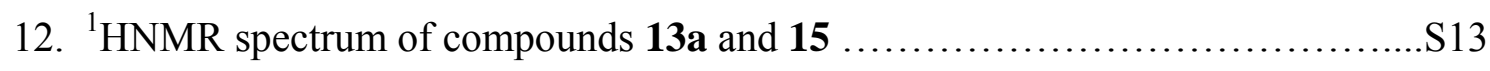

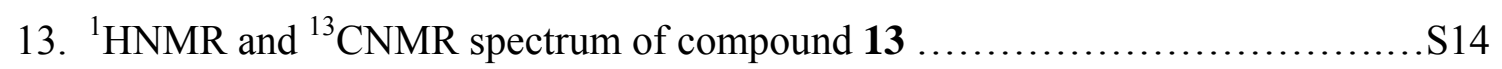

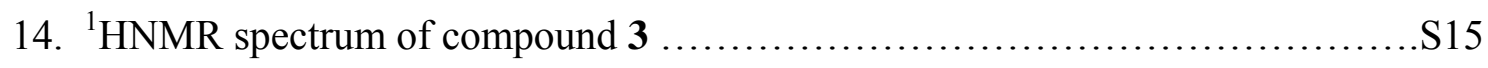


To a solution of $4(250 \mathrm{mg}, 1.5 \mathrm{mmol})$ in pyridine $(2 \mathrm{~mL})$ was added DMAP $(150 \mathrm{mg})$ and tosyl chloride (570 mg, $3 \mathrm{mmol}$ ). The mixture was stirred for $3 \mathrm{~h}$ at $60{ }^{\circ} \mathrm{C}$, cooled to room temperature, and neutralized with cold dilute $\mathrm{HCl}$. The mixture was extracted with ether, dried over anhydrous sodium sulfate, filtered and concentrated. Chromatography of the crude product on silica gel (EtOAc / petroleum ether 1:50) provided $480 \mathrm{mg}(100 \%)$ of tosylate $4 a$ as white solids, mp. $93-94{ }^{\circ} \mathrm{C}$; IR (film) $v_{\max } 1750$, 1360, 1181, 970, $809 \mathrm{~cm}^{-1} ;{ }^{1} \mathrm{H}$ NMR $\left(300 \mathrm{MHz}, \mathrm{CDCl}_{3}\right) \delta 0.48-0.78(\mathrm{~m}, 4 \mathrm{H}), 1.42-2.41(\mathrm{~m}, 7 \mathrm{H})$, $2.46(\mathrm{~s}, 3 \mathrm{H}), 3.92(\mathrm{~d}, J=11.1 \mathrm{~Hz}, 1 \mathrm{H}), 4.06(\mathrm{~d}, J=10.5 \mathrm{~Hz}, 1 \mathrm{H}), 7.36(\mathrm{~d}, J=8.1 \mathrm{~Hz}, 2 \mathrm{H}), 7.77(\mathrm{~d}, J$ $=8.1 \mathrm{~Hz}, 2 \mathrm{H}) \mathrm{ppm} ;{ }^{13} \mathrm{C}$ NMR $\left(75 \mathrm{MHz}, \mathrm{CDCl}_{3}\right) \delta 4.00,5.06,21.6,26.3,26.6,35.3,41.4,45.0,55.9$, $66.0,128.0,128.0,129.8,129.8,132.0,145.0,213.6 \mathrm{ppm}$; HRMS (ESI) $\mathrm{m} / \mathrm{z}\left[\mathrm{M}+\mathrm{NH}_{4}\right]^{+}$found 338.1418; calcd 338.1421 for $\mathrm{C}_{17} \mathrm{H}_{24} \mathrm{O}_{4} \mathrm{SN}$.

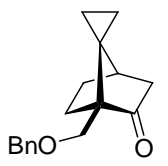

(4b)

To a stirred suspension of sodium hydride (100 mg in 60\% oil, $2.5 \mathrm{mmol})$ in dry THF ( $3 \mathrm{~mL}$ ) was added dropwise a solution of alcohol $4(332 \mathrm{mg}, 2.0 \mathrm{mmol})$ in $3 \mathrm{~mL}$ of THF at $0{ }^{\circ} \mathrm{C}$ under $\operatorname{argon}$ atmosphere. After stirring for $20 \mathrm{~min}, 0.3 \mathrm{~mL}$ of benzyl bromide was added at same temperature and the resulting mixture was continued to stir for $3 \mathrm{~h}$. The reaction was quenched with saturated aqueous $\mathrm{NH}_{4} \mathrm{Cl}$, extracted with ether. The combined organic phases were dried over anhydrous sodium sulfate, filtered, and concentrated. Chromatography of the crude product on silica gel (EtOAc / petroleum ether 1:100) afforded $440 \mathrm{mg}(85 \%)$ of $\mathbf{4 b}$ as a colorless oil. IR (film) $v_{\max } 2954,2869,1741,1102,1049$, $739 \mathrm{~cm}^{-1} ;{ }^{1} \mathrm{H}$ NMR $\left(300 \mathrm{MHz}, \mathrm{CDCl}_{3}\right) \delta 0.40-0.54(\mathrm{~m}, 2 \mathrm{H}), 0.71-0.78(\mathrm{~m}, 2 \mathrm{H}), 1.42-2.43(\mathrm{~m}, 7 \mathrm{H})$, 3.47 (s, 2H), 4.45 (s, 2H), 7.24-7.36 (m, 5H) ppm; ${ }^{13} \mathrm{C}$ NMR (75 MHz, $\left.\mathrm{CDCl}_{3}\right) \delta$ 4.24, 5.11, 26.8, 35.5, 41.5, 45.5, 57.2, 65.9, 73.5, 127.4, 127.4, 127.4, 128.3, 128.3, 138.3, $216.1 \mathrm{ppm}$; LRMS (EI) m/z 256 $\left(\mathrm{M}^{+}, 0.6 \%\right), 165$ (1), 150 (17), 91 (100), 77(13); HRMS (SMS) $\mathrm{m} / \mathrm{z}[\mathrm{M}+\mathrm{H}]^{+}$found 257.1543; calcd 257.1536 for $\mathrm{C}_{17} \mathrm{H}_{21} \mathrm{O}_{2}$.<smiles>COC1CC2(CC2)CC(=O)C1CO</smiles>

(4c) 
To a stirred suspension of sodium hydride (50 mg in $60 \%$ oil, $1.25 \mathrm{mmol}$ ) in dry THF (2 mL) was added dropwise a solution of alcohol $4(166 \mathrm{mg}, 1.0 \mathrm{mmol})$ in $2 \mathrm{~mL}$ of THF at $0{ }^{\circ} \mathrm{C}$ under argon atmosphere. After stirring for $20 \mathrm{~min}, 0.1 \mathrm{~mL}$ of methyl iodide was added at same temperature and the resulting mixture was continued to stir for $30 \mathrm{~min}$. The reaction was quenched with saturated aqueous $\mathrm{NH}_{4} \mathrm{Cl}$, extracted with ether. The combined organic phases were dried over anhydrous sodium sulfate, filtered, and concentrated. Chromatography of the crude product on silica gel (EtOAc / petroleum ether 1:100) afforded $150 \mathrm{mg}(85 \%)$ of $4 \mathrm{c}$ as a colorless oil. IR (film) $v_{\max } 2955,2873,1744,1111,1051$ $\mathrm{cm}^{-1} ;{ }^{1} \mathrm{H}$ NMR $\left(300 \mathrm{MHz}, \mathrm{CDCl}_{3}\right) \delta$ 0.41-0.74 (m, 4H), 1.42-2.43 (m, 7H), $3.26(\mathrm{~s}, 3 \mathrm{H}), 3.38(\mathrm{~s}, 2 \mathrm{H})$ ppm; ${ }^{13} \mathrm{C}$ NMR (75 MHz, $\left.\mathrm{CDCl}_{3}\right) \delta$ 4.22, 4.88, 26.7, 26.8, 35.4, 41.5, 45.5, 57.1, 59.4, 68.5, 215.9 ppm; LRMS (EI) m/z 180 (M+, 7\%), 135 (18), 106 (96), 91 (100), 79 (91), 71 (38); HRMS (ESI) m/z $[2 \mathrm{M}+\mathrm{Na}]^{+}$found 383.2192 ; calcd 383.2193 for $\mathrm{C}_{22} \mathrm{H}_{32} \mathrm{O}_{4} \mathrm{Na}$.

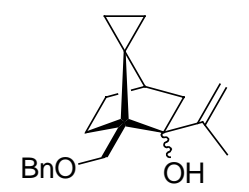

\section{2 (endo-OH / exo-OH 1:1)}

To a vigorously stirred slurry of anhydrous $\mathrm{CeCl}_{3}(370 \mathrm{mg}, 1.5 \mathrm{mmol})$ in $8 \mathrm{~mL}$ of dry THF was added dropwise isopropenyl magnesium bromide $(3.0 \mathrm{~mL}, 1.5 \mathrm{mmol}, 0.5 \mathrm{M})$ at $0{ }^{\circ} \mathrm{C}$, and the mixture was stirred for $50 \mathrm{~min}$ at $0{ }^{\circ} \mathrm{C}$ before the addition of a solution of ketone $4 \mathbf{b}(260 \mathrm{mg}, 1.0 \mathrm{mmol})$ in $2 \mathrm{~mL}$ of THF. The resulting mixture was continued to stir at same temperature for $30 \mathrm{~min}$, then quenched with addition of cold dilute $\mathrm{HCl}(1 \mathrm{~mL})$ and extracted with ether. The combined organic layers were washed with brine, dried $\left(\mathrm{Na}_{2} \mathrm{SO}_{4}\right)$ and concentrated in vacuo. The residue was purified by chromatography on silica gel (EtOAc / petroleum ether 1:60) to afford $230 \mathrm{mg}(80 \%)$ of $\mathbf{1 2}$ as colorless oil (mixture of diastereomers). IR (film) $v_{\max } 3498,2946,1634,1102,1077 \mathrm{~cm}^{-1} ;{ }^{1} \mathrm{H}$ NMR $\left(300 \mathrm{MHz}, \mathrm{CDCl}_{3}\right) \delta$ 0.13-0.76 (m, 7H), 1.08-1.96 (m, 13H), $1.87(\mathrm{~s}, 3 \mathrm{H}), 1.90(\mathrm{~s}, 3 \mathrm{H}), 2.36-2.59(\mathrm{~m}, 3 \mathrm{H}), 2.99(\mathrm{~d}, J=$ $9 \mathrm{~Hz}, 1 \mathrm{H}), 3.32(\mathrm{~d}, J=10.2 \mathrm{~Hz}, 1 \mathrm{H}), 3.35(\mathrm{~d}, J=8.1 \mathrm{~Hz}, 1 \mathrm{H}), 3.60(\mathrm{~d}, J=10.5 \mathrm{~Hz}, 1 \mathrm{H}), 4.28-4.50$ $(\mathrm{m}, 4 \mathrm{H}), 4.69(\mathrm{~s}, 1 \mathrm{H}), 4.91(\mathrm{~s}, 1 \mathrm{H}), 5.01(\mathrm{~s}, 1 \mathrm{H}), 5.04(\mathrm{~s}, 2 \mathrm{H}), 7.25-7.36(\mathrm{~m}, 10 \mathrm{H}) \mathrm{ppm} ;{ }^{13} \mathrm{C} \mathrm{NMR}$ $\left(75 \mathrm{MHz}, \mathrm{CDCl}_{3}\right) \delta 1.45,2.50,7.61,8.04,21.2,27.6,28.0,28.4,28.9,35.9,36.4,43.1,43.9,45.4$, $45.6,51.8,53.5,70.8,71.5,73.3,73.8,84.4,85.3,112.2,113.6,127.3,127.5,127.6,127.8,128.3$, 128.4, 137.1, 138.1, 147.8, 151.1 ppm; HRMS (ESI) $\mathrm{m} / \mathrm{z}[\mathrm{M}+\mathrm{Na}]^{+}$found 321.1820; calcd 321.1825 for $\mathrm{C}_{20} \mathrm{H}_{26} \mathrm{O}_{2} \mathrm{Na}$. 


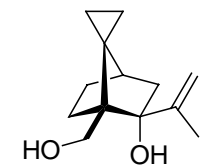

(13a)

To a vigorously stirred slurry of anhydrous $\mathrm{CeCl}_{3}(930 \mathrm{mg}, 3.75 \mathrm{mmol})$ in $20 \mathrm{~mL}$ of dry THF was added dropwise isopropenyl magnesium bromide $(7.5 \mathrm{~mL}, 3.75 \mathrm{mmol}, 0.5 \mathrm{M})$ at $0{ }^{\circ} \mathrm{C}$, and the mixture was stirred for $50 \mathrm{~min}$ at $0{ }^{\circ} \mathrm{C}$ before the addition of a solution of ketone $4(250 \mathrm{mg}, 1.5 \mathrm{mmol})$ in $5 \mathrm{~mL}$ of THF. The resulting mixture was continued to stir at same temperature for $30 \mathrm{~min}$, then quenched with addition of cold dilute $\mathrm{HCl}(2 \mathrm{~mL})$ and extracted with ether. The combined organic layers were washed with brine, dried $\left(\mathrm{Na}_{2} \mathrm{SO}_{4}\right)$ and concentrated in vacuo. The residue was purified by chromatography on silica gel (EtOAc / petroleum ether 1:20) to afford $100 \mathrm{mg}$ of 13a as a colorless oil, along with $150 \mathrm{mg}$ of its exo-OH isomer, in a combined yield of $80 \%$. 13a, IR (film) $v_{\max } 3404,2946,1633,1455$, $991 \mathrm{~cm}^{-1} ;{ }^{1} \mathrm{H}$ NMR $\left(300 \mathrm{MHz}, \mathrm{CDCl}_{3}\right) \delta 0.17-0.25(\mathrm{~m}, 2 \mathrm{H}), 0.58-0.65(\mathrm{~m}, 2 \mathrm{H}), 1.36-1.86(\mathrm{~m}, 6 \mathrm{H})$, $1.98(\mathrm{~s}, 3 \mathrm{H}), 2.40-2.53(\mathrm{~m}, 3 \mathrm{H}), 3.19-3.59(\mathrm{~m}, 1 \mathrm{H}), 5.08(\mathrm{~s}, 1 \mathrm{H}), 5.11(\mathrm{~s}, 1 \mathrm{H}) \mathrm{ppm} ;{ }^{13} \mathrm{C} \mathrm{NMR}(75$ $\left.\mathrm{MHz}, \mathrm{CDCl}_{3}\right) \delta 2.68,8.13,21.5,28.1,28.3,35.9,44.0,46.0,54.2,63.5,84.5,113.8,151.0 \mathrm{ppm} ;$ HRMS (ESI) $\mathrm{m} / \mathrm{z}[\mathrm{M}+\mathrm{Na}]^{+}$found 231.1361; calcd 231.1356 for $\mathrm{C}_{13} \mathrm{H}_{20} \mathrm{O}_{2} \mathrm{Na}$.

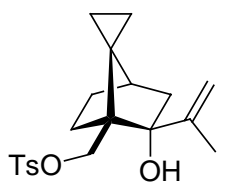

(13)

To a solution of 13a $(100 \mathrm{mg}, 0.48 \mathrm{mmol})$ in pyridine $(2 \mathrm{~mL})$ was added DMAP $(150 \mathrm{mg})$ and tosyl chloride (410 mg, $2.16 \mathrm{mmol}$ ). The mixture was stirred overnight at $60{ }^{\circ} \mathrm{C}$, cooled to room temperature, and neutralized with cold dilute $\mathrm{HCl}$. The mixture was extracted with ether, dried over anhydrous sodium sulfate, filtered and concentrated. Chromatography of the crude product on silica gel (EtOAc / petroleum ether 1:60) provided $148 \mathrm{mg}(85 \%)$ of tosylate 13 as a colorless oil. IR (film) $v_{\max } 3543$, 2950, 1359, 1175, $958 \mathrm{~cm}^{-1} ;{ }^{1} \mathrm{H}$ NMR $\left(300 \mathrm{MHz}, \mathrm{CDCl}_{3}\right) \delta 0.19-0.27(\mathrm{~m}, 2 \mathrm{H}), 0.54-0.64(\mathrm{~m}, 2 \mathrm{H})$, $1.35-1.79(\mathrm{~m}, 5 \mathrm{H}), 1.82(\mathrm{~s}, 3 \mathrm{H}), 1.90(\mathrm{~s}, 1 \mathrm{H}), 2.23-2.45(\mathrm{~m}, 2 \mathrm{H}), 2.46(\mathrm{~s}, 3 \mathrm{H}), 3.61(\mathrm{~d}, J=9.3 \mathrm{~Hz}$, 1H), $3.92(\mathrm{~d}, J=9.6 \mathrm{~Hz}, 1 \mathrm{H}), 5.00(\mathrm{~s}, 1 \mathrm{H}), 5.03(\mathrm{~s}, 1 \mathrm{H}), 7.34(\mathrm{~d}, J=7.5 \mathrm{~Hz}, 2 \mathrm{H}), 7.74(\mathrm{~d}, J=8.1 \mathrm{~Hz}$, 2H) ppm; ${ }^{13} \mathrm{C} \mathrm{NMR}\left(75 \mathrm{MHz}, \mathrm{CDCl}_{3}\right) \delta 3.25,7.77,21.2,21.7,27.6,27.7,36.7,43.9,46.4,52.7,71.1$, 83.6, 114.3, 127.9, 127.9, 129.8, 129.8, 132.4, 144.9, $149.3 \mathrm{ppm}$; HRMS (ESI) $\mathrm{m} / \mathrm{z}\left[\mathrm{M}+\mathrm{NH}_{4}\right]^{+}$found 380.1889; calcd 380.1890 for $\mathrm{C}_{20} \mathrm{H}_{30} \mathrm{O}_{4} \mathrm{SN}$. 


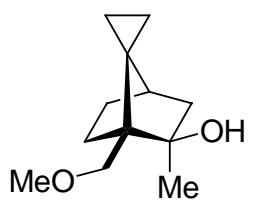

(16)

To a solution of 4c (100 mg, $0.55 \mathrm{mmol})$ in anhydrous diethyl ether $(4 \mathrm{~mL})$ was added dropwise $\mathrm{CH}_{3} \mathrm{Li}\left(0.68 \mathrm{~mL}, 1.1 \mathrm{mmol}, 1.6 \mathrm{M}\right.$ in ether) under argon at $-20^{\circ} \mathrm{C}$. After stirring for $1 \mathrm{~h}$, the reaction was quenched by dropwise addition of saturated aqueous $\mathrm{NH}_{4} \mathrm{Cl}(1 \mathrm{~mL})$, diluted and extracted with ether. The combined organic layers were washed with brine, dried $\left(\mathrm{Na}_{2} \mathrm{SO}_{4}\right)$ and concentrated in vacuo. Chromatography of the crude product on silica gel (EtOAc / petroleum ether 1:60) provided $30 \mathrm{mg}$ of $\mathbf{1 6}$ as a colorless oil, along with $60 \mathrm{mg}$ of its endo-OH isomer, in a combined yield of $80 \%$. 16, IR (film) $v_{\max } 3496,2934,2870,1187,1103 \mathrm{~cm}^{-1} ;{ }^{1} \mathrm{H}$ NMR $\left(300 \mathrm{MHz}, \mathrm{CDCl}_{3}\right) \delta$ 0.24-0.92 (m, 4H), 1.14-1.96 $(\mathrm{m}, 8 \mathrm{H}), 1.34(\mathrm{~s}, 3 \mathrm{H}), 3.26(\mathrm{~s}, 3 \mathrm{H}), 3.32-3.41(\mathrm{~m}, 2 \mathrm{H}) \mathrm{ppm} ;{ }^{13} \mathrm{C} \mathrm{NMR}\left(75 \mathrm{MHz}, \mathrm{CDCl}_{3}\right) \delta 1.7,6.4,24.3$, 27.9, 28.3, 35.5, 43.3, 49.2, 51.4, 59.4, 72.3, 80.3 ppm; LRMS (EI) m/z 164 ([M- $\left.\left.\mathrm{HOCH}_{3}\right]^{+}, 4 \%\right), 149$ (14), $121(26), 106$ (100), 91 (62).

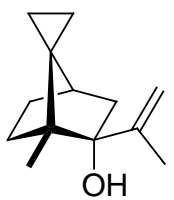

(I)

To a well stirred slurry of anhydrous $\mathrm{CeCl}_{3}(75 \mathrm{mg}, 0.3 \mathrm{mmol})$ in $1 \mathrm{~mL}$ of dry THF was added dropwise isopropenyl magnesium bromide $(0.6 \mathrm{~mL}, 0.3 \mathrm{mmol}, 0.5 \mathrm{M})$ at $0{ }^{\circ} \mathrm{C}$, and the mixture was stirred for $50 \mathrm{~min}$ at $0{ }^{\circ} \mathrm{C}$ before the addition of a solution of ketone $3(30 \mathrm{mg}, 0.2 \mathrm{mmol})$ in $0.5 \mathrm{~mL}$ of THF. The resulting mixture was continued to stir at same temperature for $30 \mathrm{~min}$, then quenched with addition of cold dilute $\mathrm{HCl}(0.5 \mathrm{~mL})$ and extracted with ether. The combined organic layers were washed with brine, dried $\left(\mathrm{Na}_{2} \mathrm{SO}_{4}\right)$ and concentrated in vacuo. The residue was purified by chromatography on silica gel (EtOAc / petroleum ether 1:80) to afford $14 \mathrm{mg}$ of $\mathbf{I}$ as colorless oil, along with $12 \mathrm{mg}$ of its exo-OH isomer, in a combined yield of $67 \%$. I, IR (film) $v_{\max } 3480,2926,1637,1458 \mathrm{~cm}^{-1} ;{ }^{1} \mathrm{H}$ NMR $\left(300 \mathrm{MHz}, \mathrm{CDCl}_{3}\right) \delta 0.25(\mathrm{t}, J=8 \mathrm{~Hz}, 2 \mathrm{H}), 0.58-0.64(\mathrm{~m}, 2 \mathrm{H}), 0.74(\mathrm{~s}, 3 \mathrm{H}), 1.22-2.17(\mathrm{~m}, 8 \mathrm{H}), 1.87$ (s, 3H), $4.97(\mathrm{~s}, 1 \mathrm{H}), 5.02(\mathrm{~s}, 1 \mathrm{H}) \mathrm{ppm} ;{ }^{13} \mathrm{C} \mathrm{NMR}\left(75 \mathrm{MHz}, \mathrm{CDCl}_{3}\right) \delta 1.19,4.29,10.9,21.6,28.2$, 31.0, 37.1, 42.3, 46.7, 49.7, 84.5, 112.7, $146.6 \mathrm{ppm}$; MS (FAB) m/z $192\left(\mathrm{M}^{+}\right)$. 

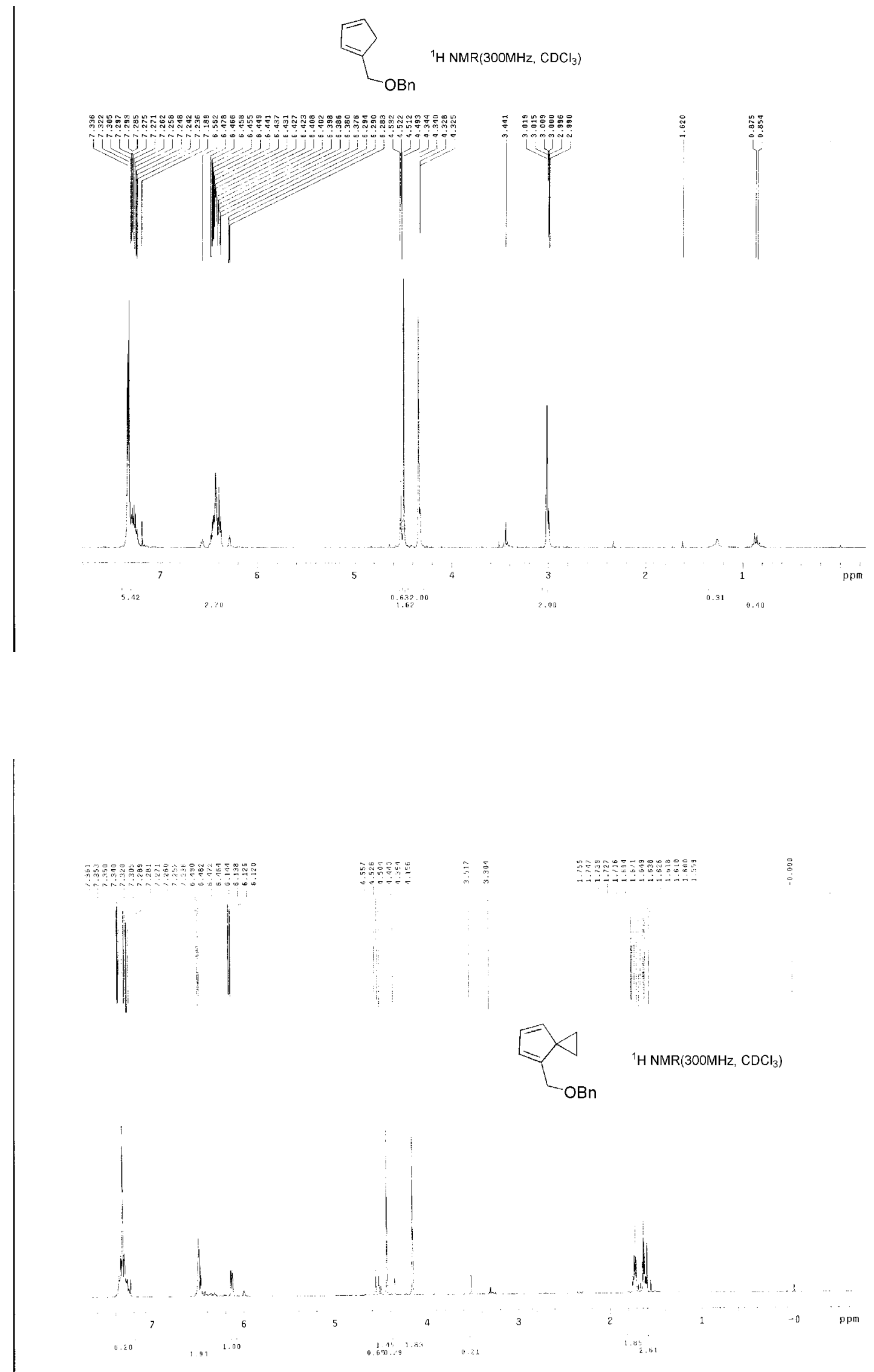

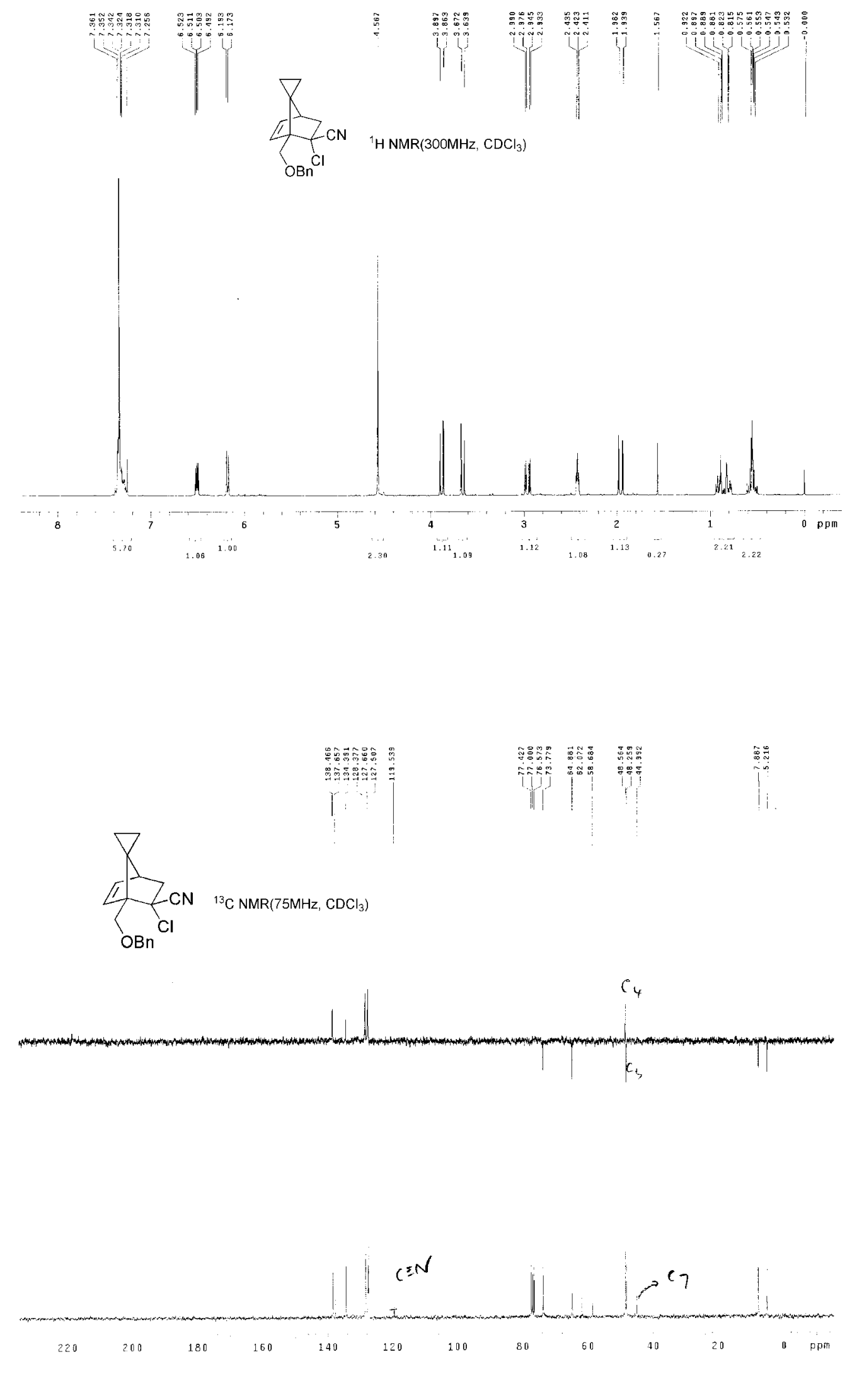


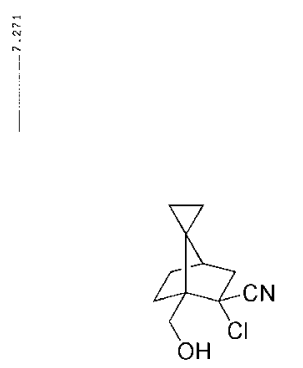

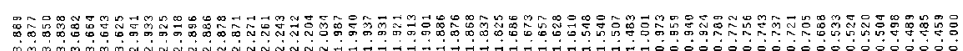

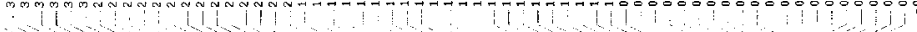

${ }^{1} \mathrm{H} \mathrm{NMR}\left(300 \mathrm{MHz}, \mathrm{CDCl}_{3}\right)$

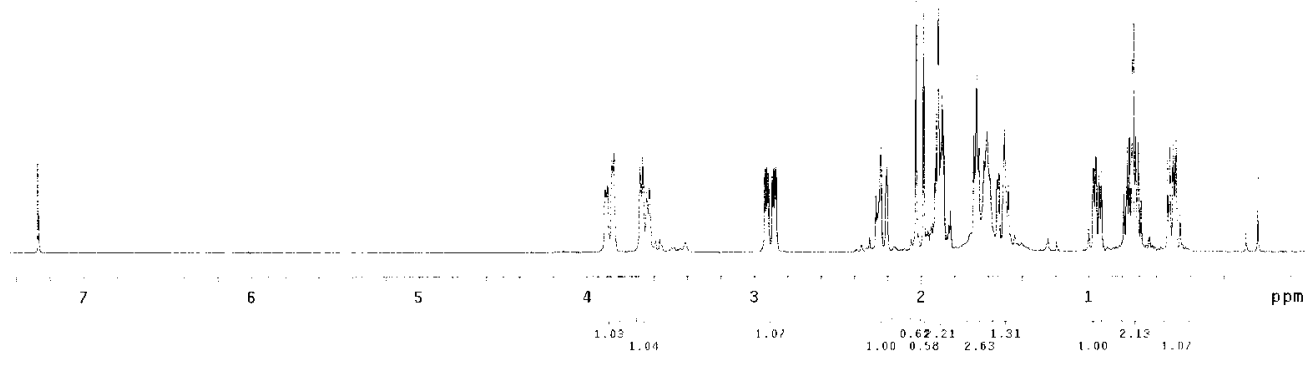

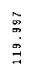

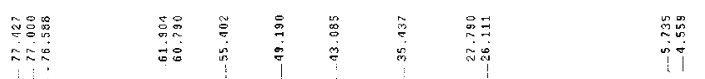

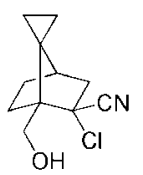

${ }^{13} \mathrm{C} \mathrm{NMR}\left(75 \mathrm{MHz}, \mathrm{CDCl}_{3}\right)$

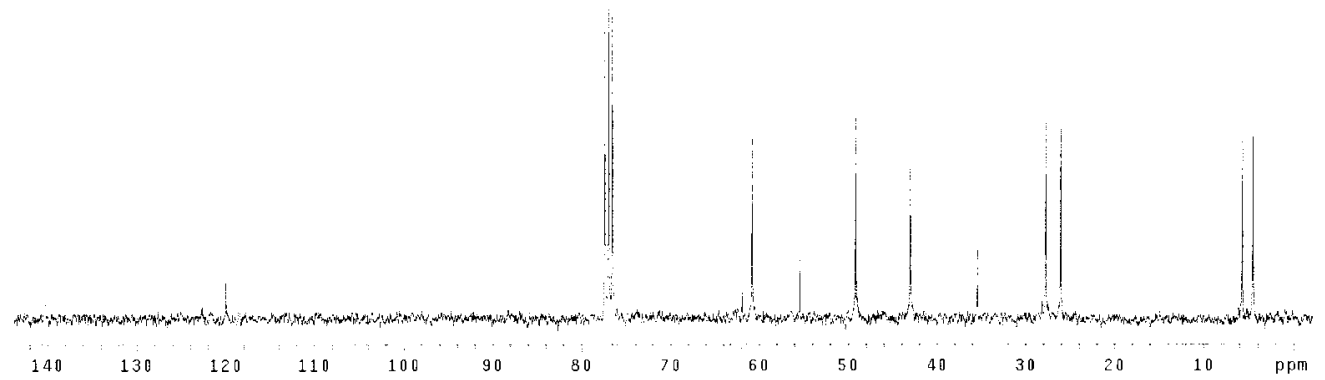




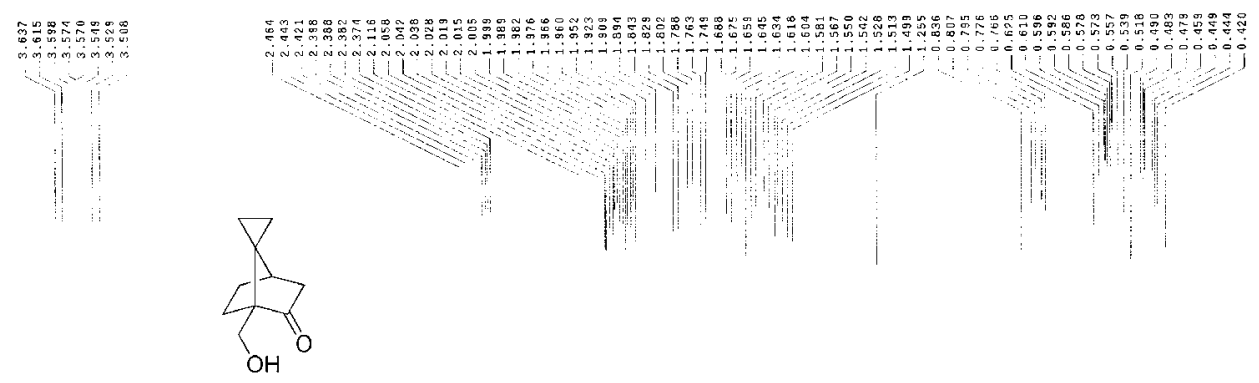

${ }^{1} \mathrm{H} \mathrm{NMR}\left(300 \mathrm{MHz}, \mathrm{CDCl}_{3}\right)$

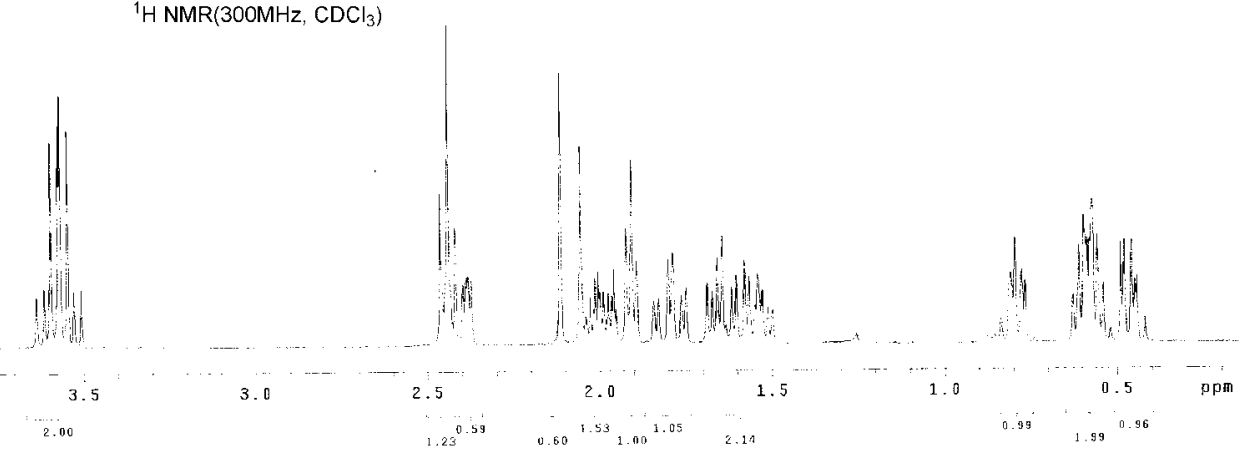

$\stackrel{\infty}{\exists}$

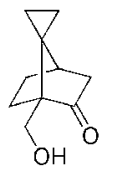

${ }^{13} \mathrm{C} \mathrm{NMR}\left(75 \mathrm{MHz}, \mathrm{CDCl}_{3}\right)$
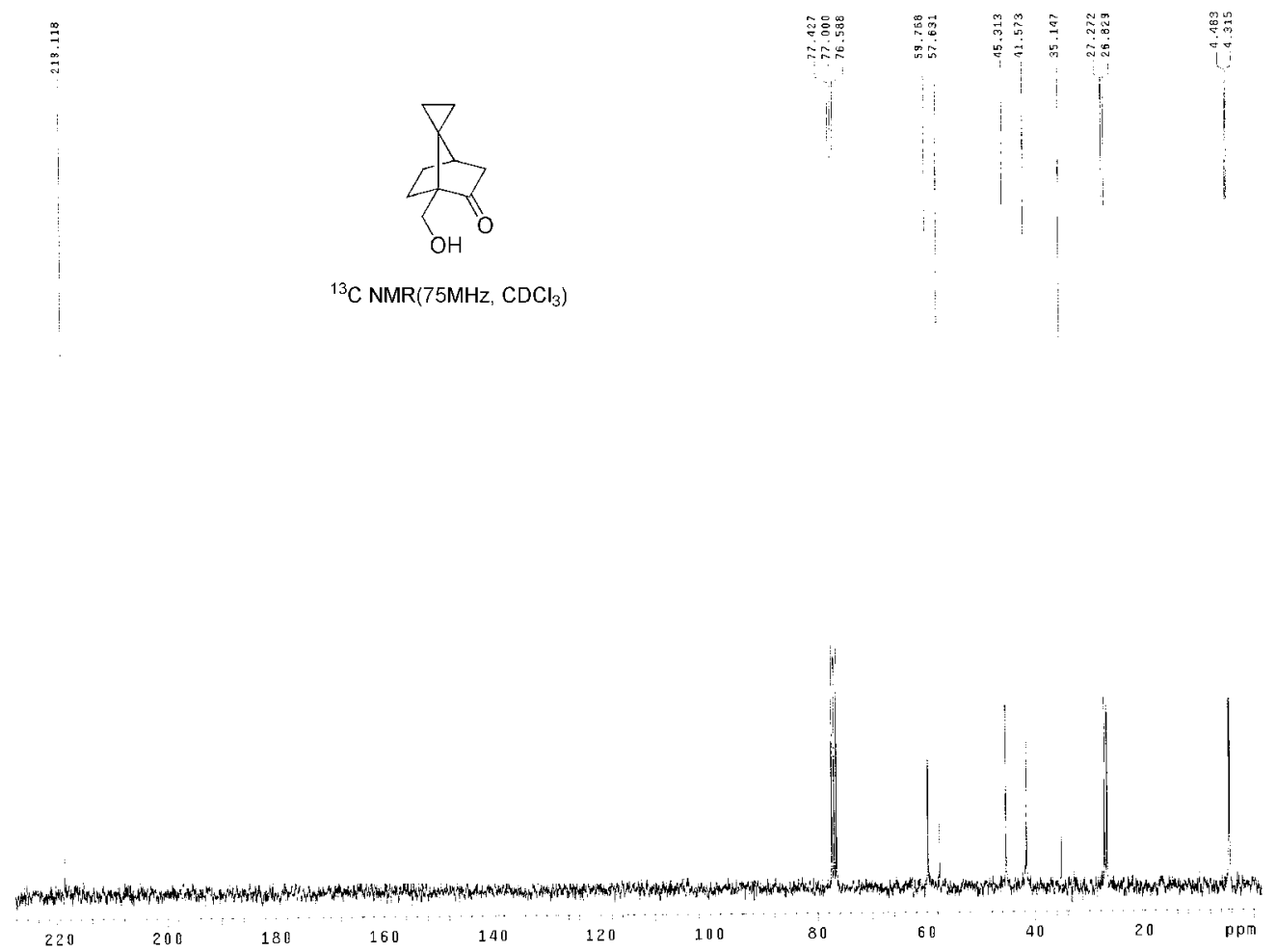


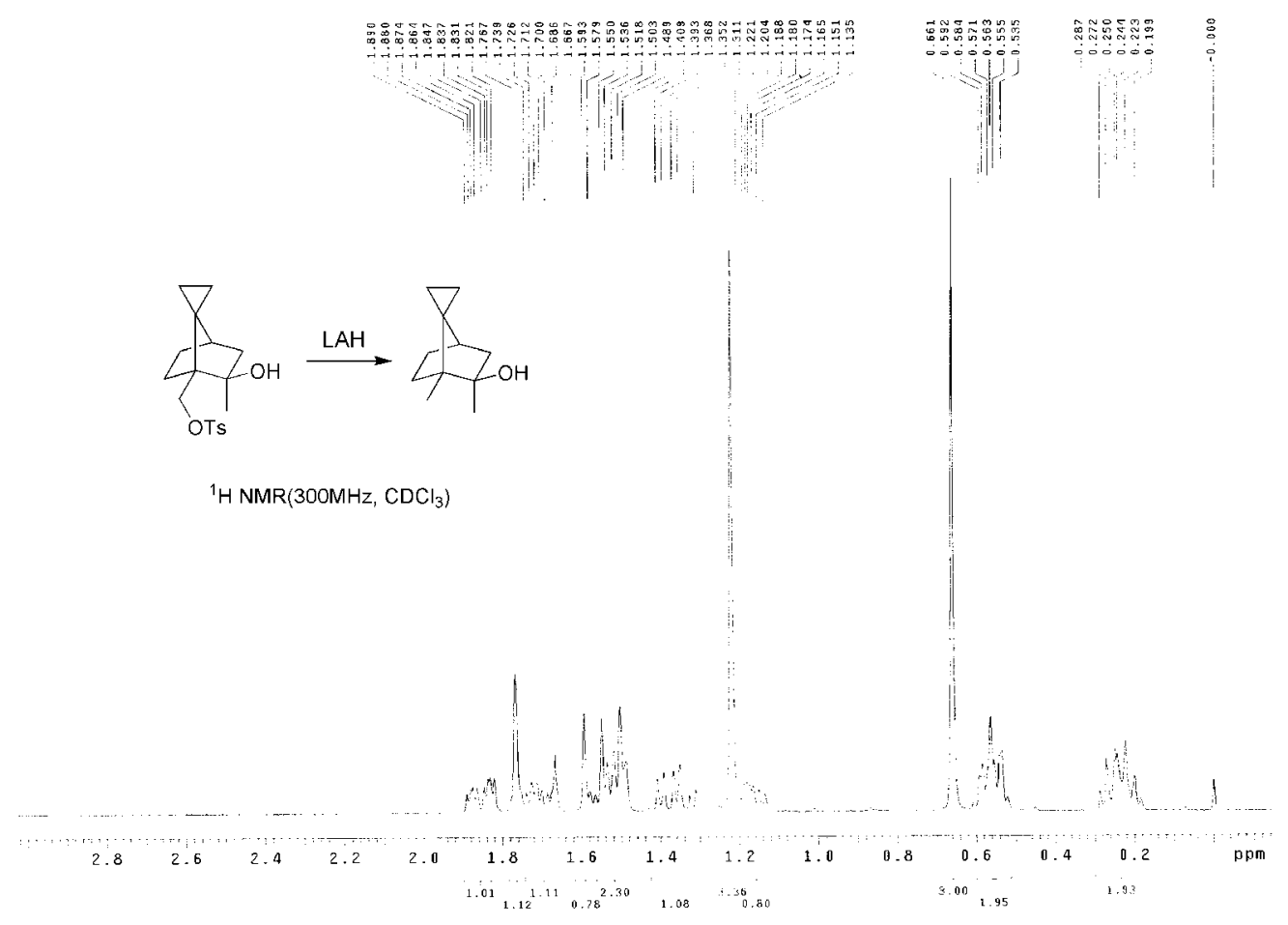

yang

Archive direct
Sample director:
File: PRoton

pulse sequence: s2pul

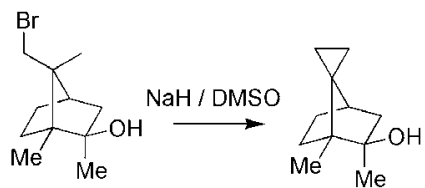

(+)

$(+)$

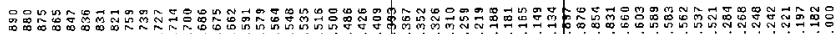

H

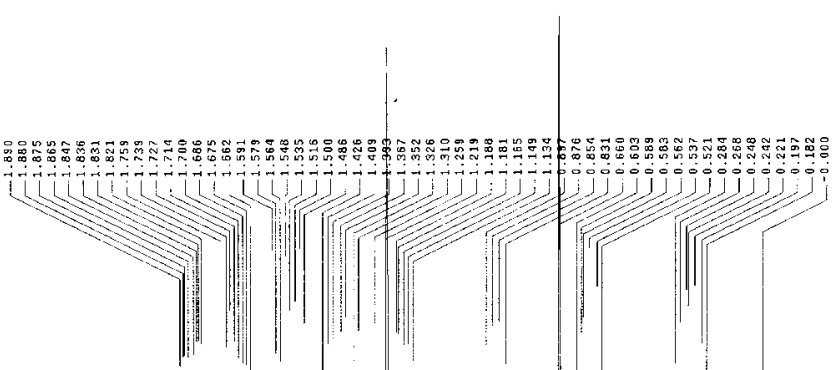

${ }^{1} \mathrm{H} \mathrm{NMR}\left(30 \mathrm{MHz}, \mathrm{CDCl}_{3}\right)$

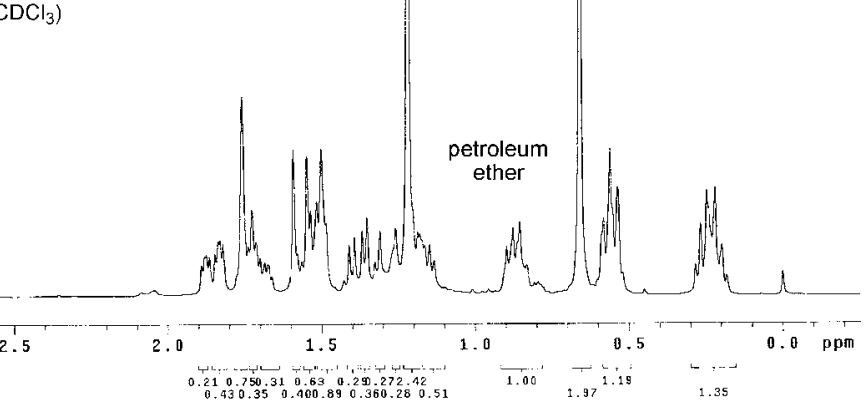




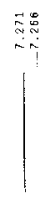

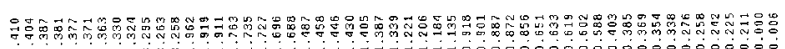

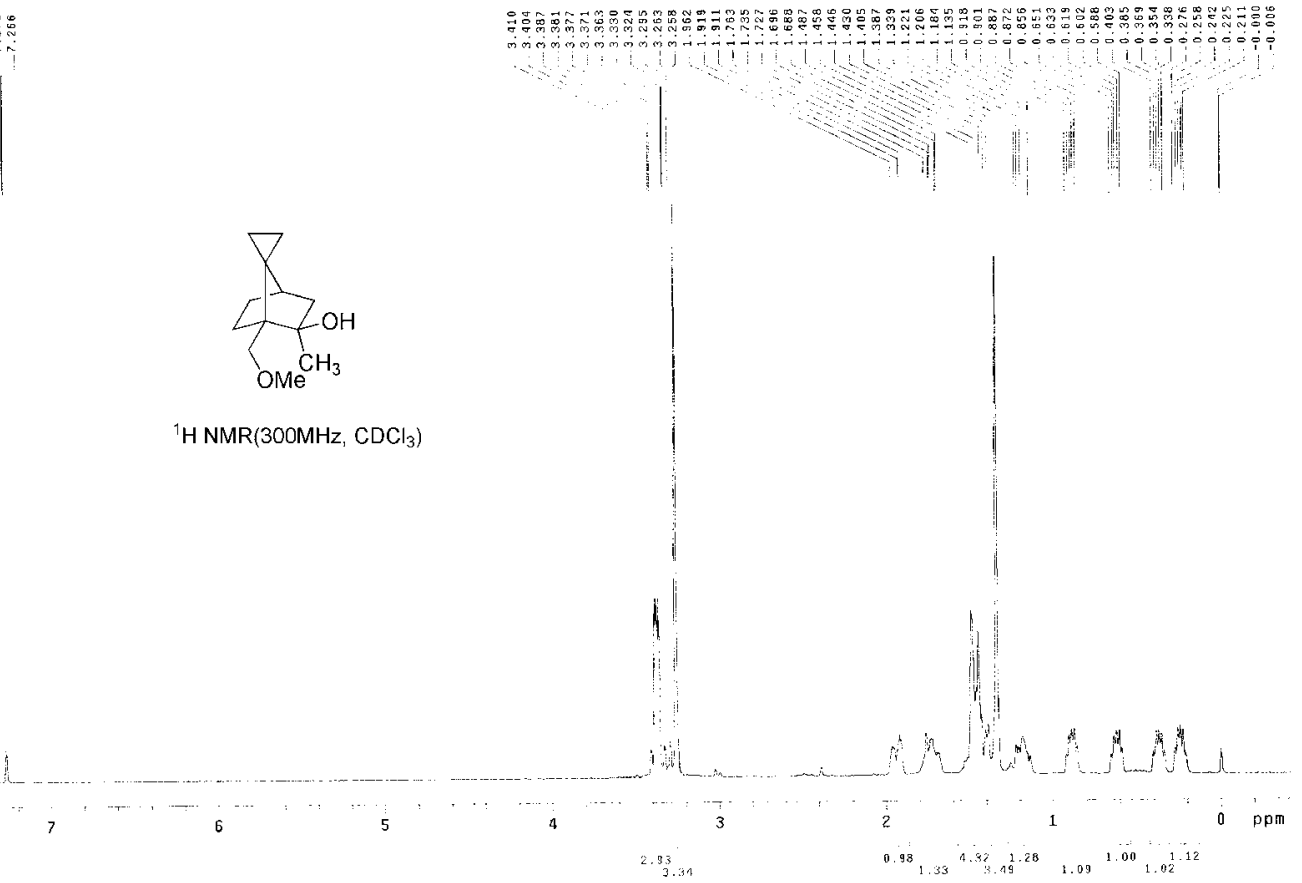

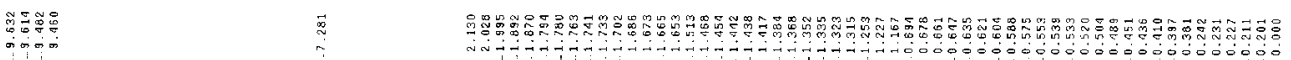

$\|$
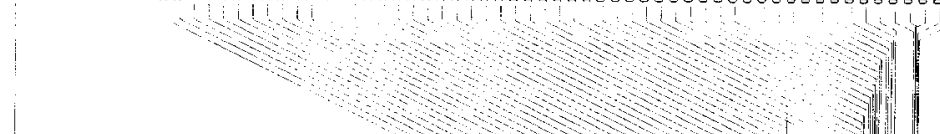<smiles>CC1CC2C(C)CC1C21CC1</smiles>

${ }^{1} \mathrm{H} \mathrm{NMR}\left(300 \mathrm{MHz}, \mathrm{CDCl}_{3}\right)$

I<smiles>C1=CCCCC1</smiles>

0.98 .16

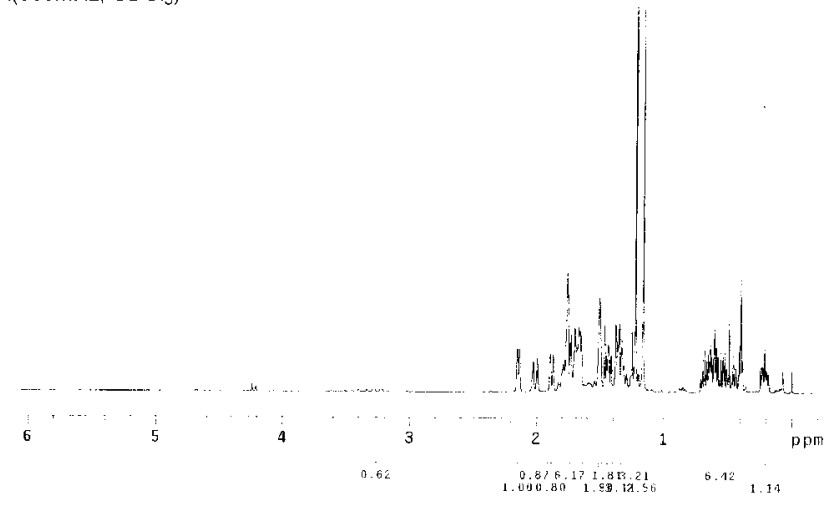



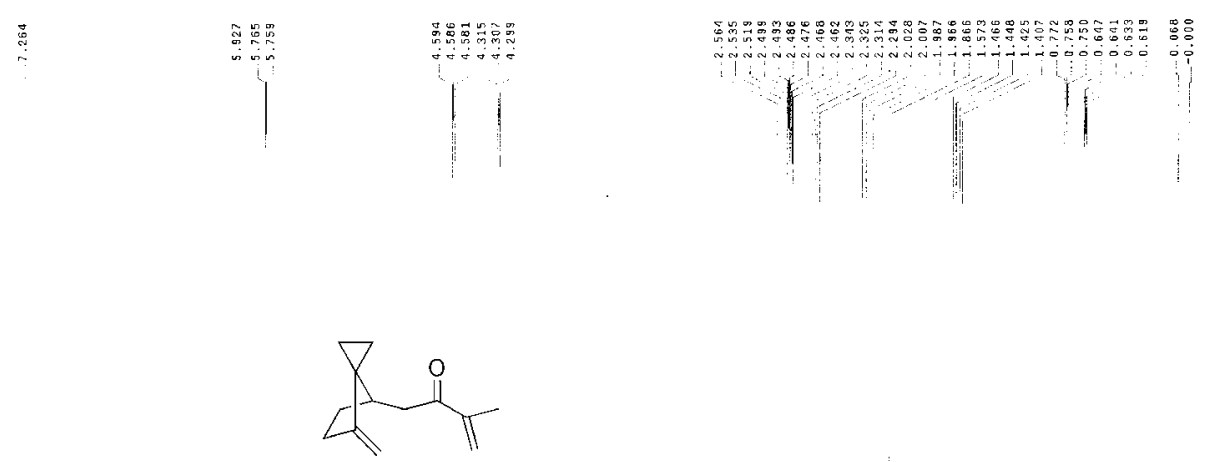

${ }^{1} \mathrm{H} \mathrm{NMR}\left(300 \mathrm{MHz}, \mathrm{CDCl}_{3}\right)$
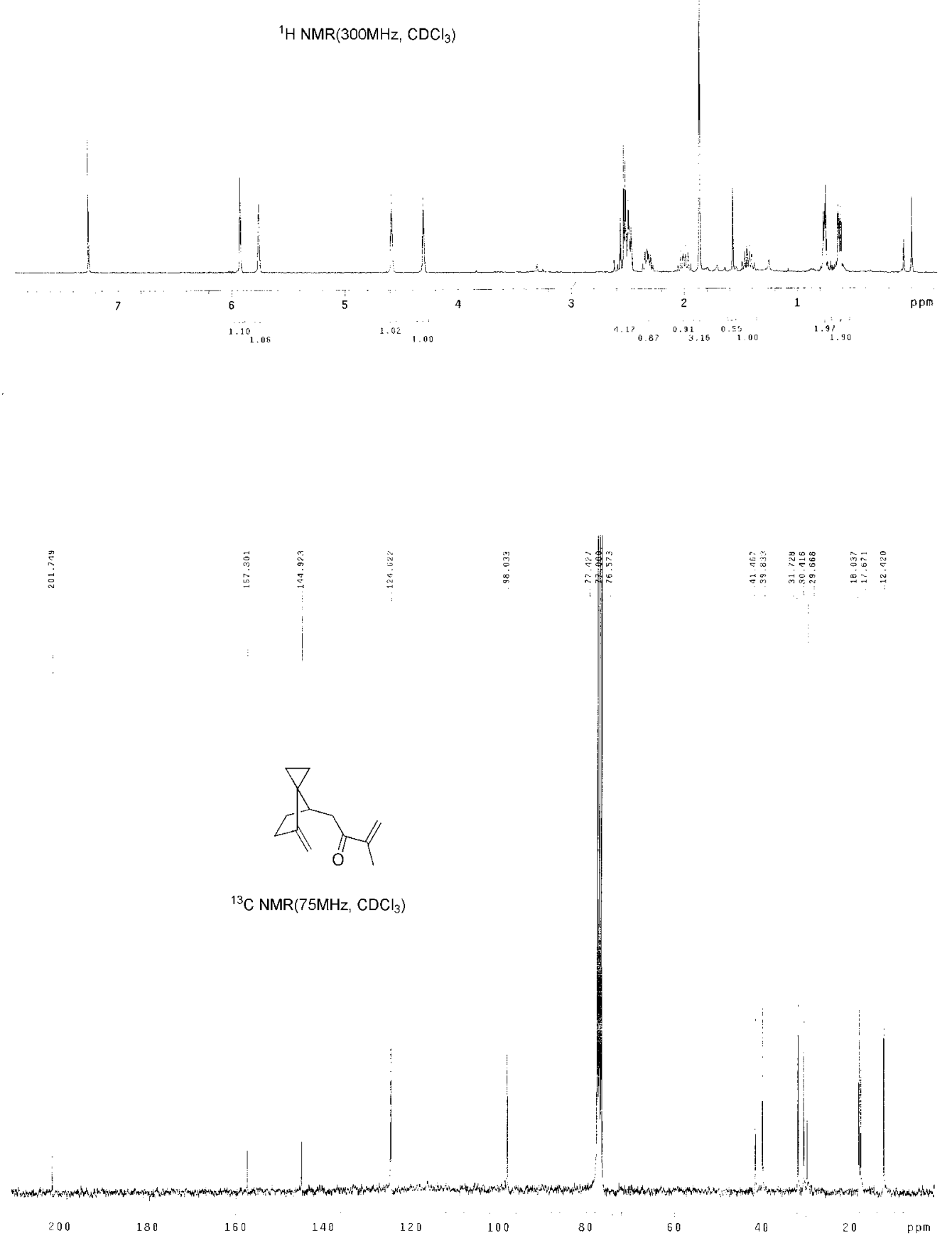

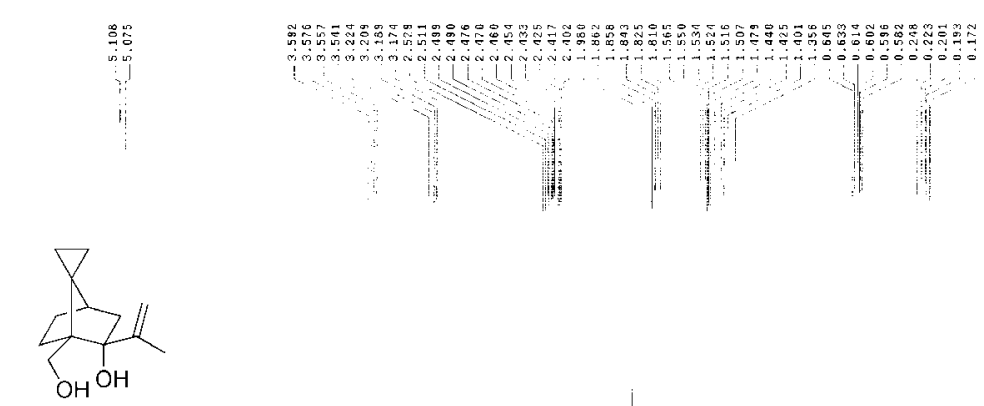

$\left.{ }^{1} \mathrm{H} \mathrm{NMR(30OMHz}, \mathrm{CDCl}_{3}\right)$

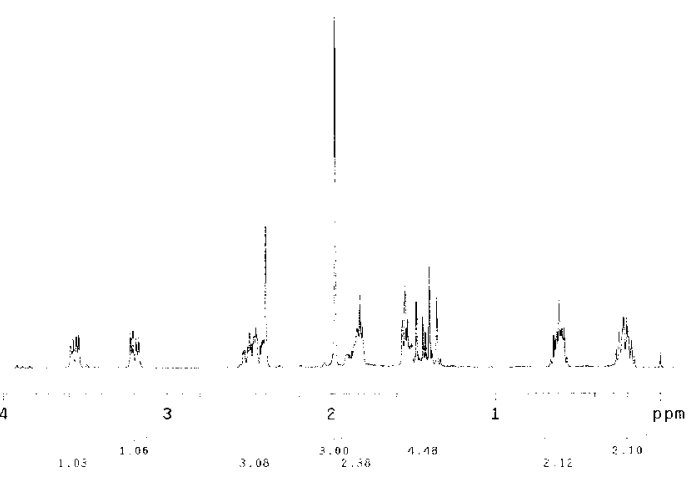

$\stackrel{\square}{\square}$
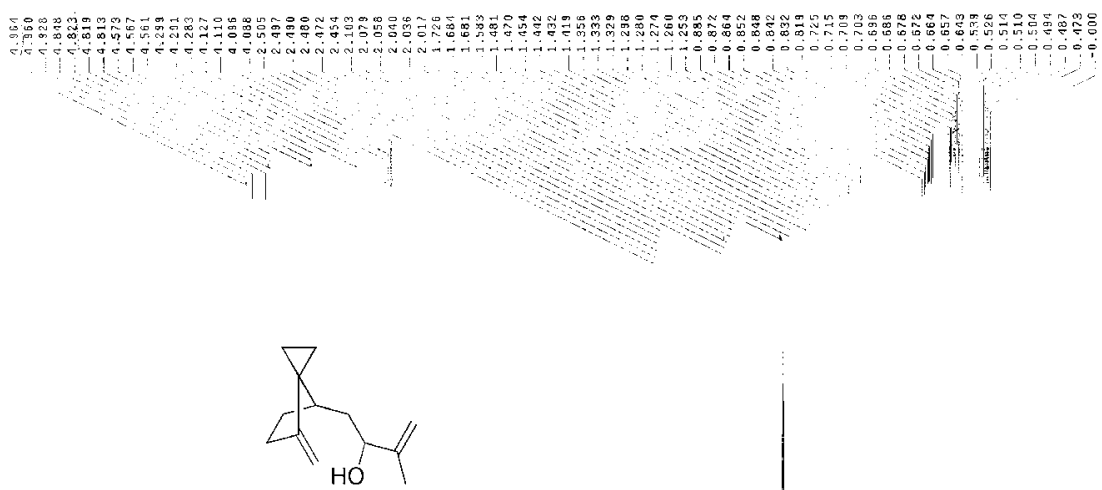

${ }^{1} \mathrm{H} \mathrm{NMR}\left(300 \mathrm{MHz}, \mathrm{CDCl}_{3}\right)$

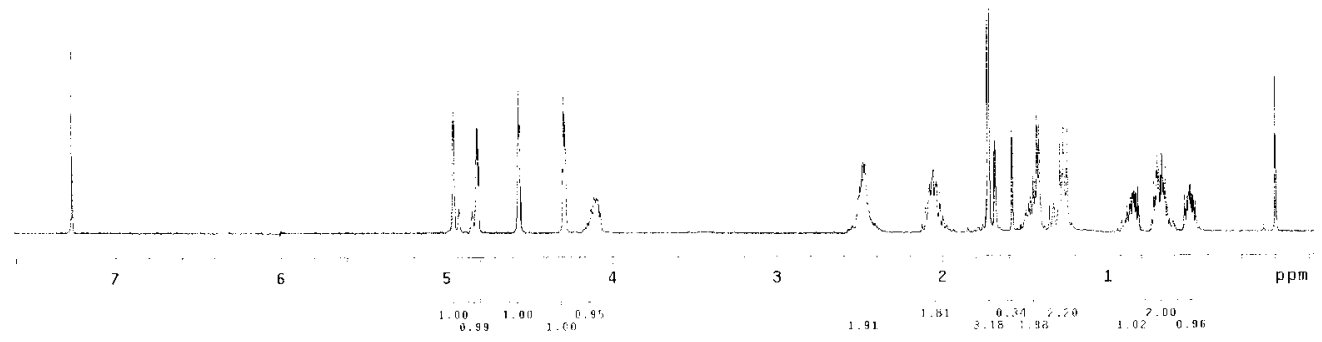



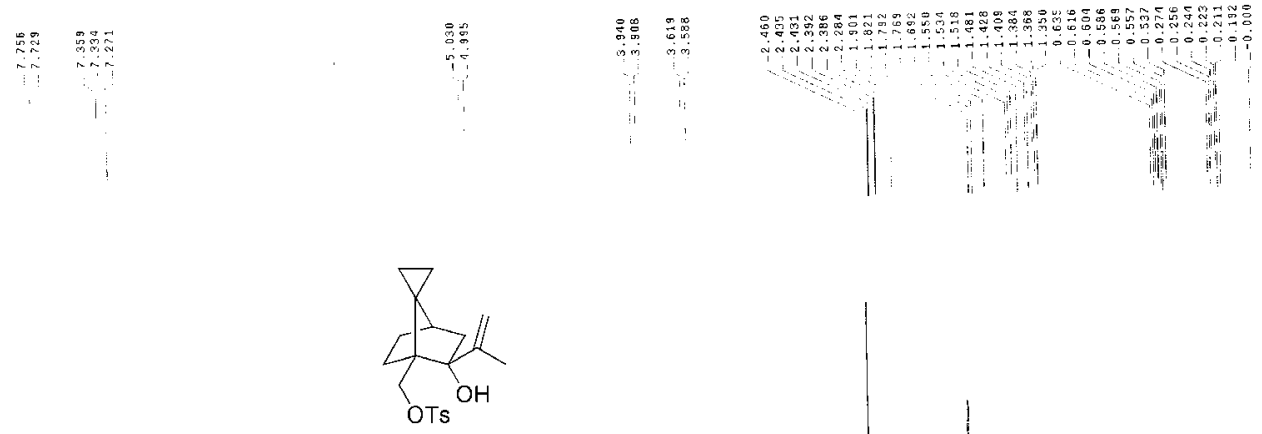

$\left.{ }^{1} \mathrm{H} \mathrm{NMR(30OMHz}, \mathrm{CDCl}_{3}\right)$
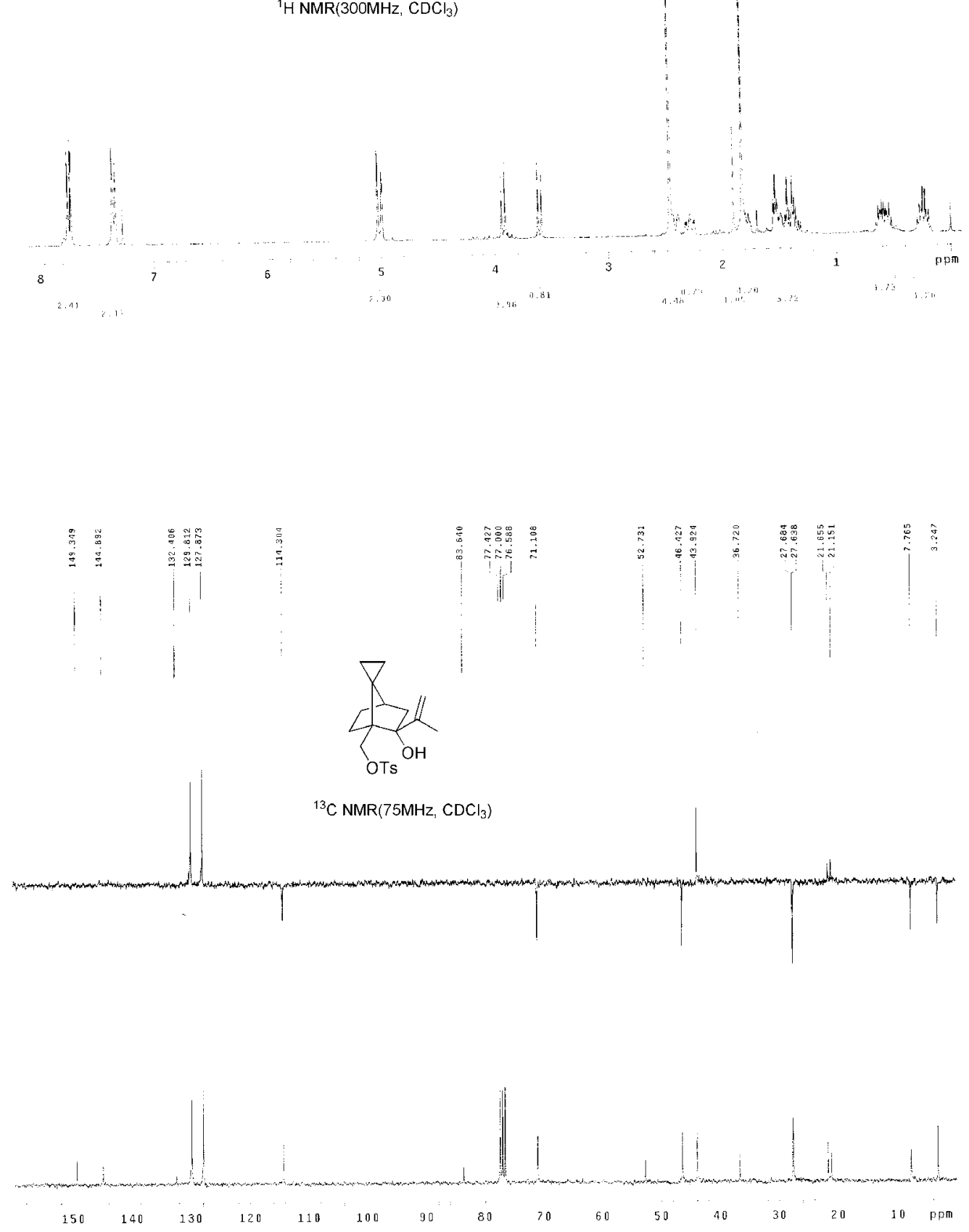


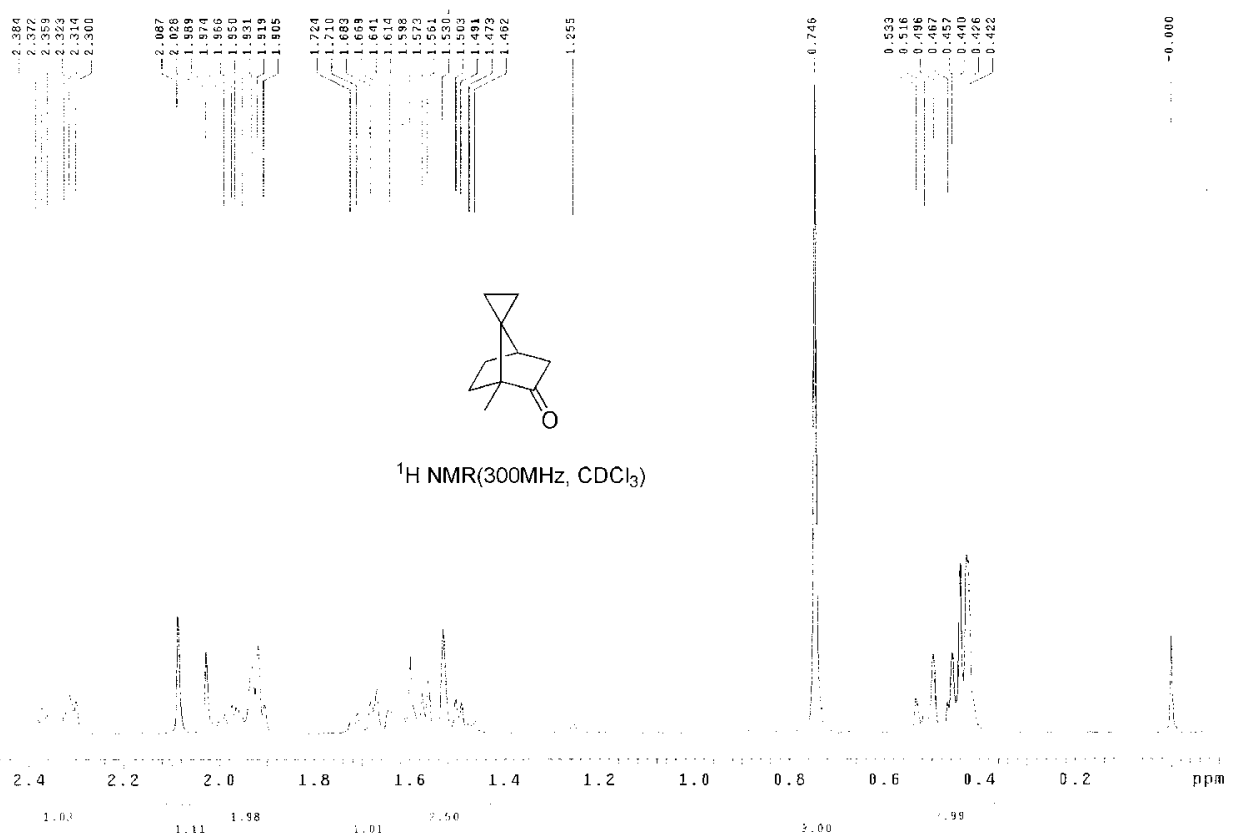

